\title{
Surviving Through the Global Downturn: Employee Motivation and Performance in Healthcare Industry
}

\author{
Abubakr M. Suliman ${ }^{*}, 1$ and Nawal Al-Sabri ${ }^{2}$ \\ ${ }^{1}$ The British University in Dubai, Block 17, Knowledge Village, Dubai, United Arab Emirates \\ ${ }^{2}$ XYZ Hospital, Northern Emirates, Ajman, United Arab Emirates
}

\begin{abstract}
This paper examines demographic variables, work motivation, job satisfaction and work performance in a government healthcare sector in the Middle East. A self administered questionnaire was developed to randomly survey 300 employees in order to examine the significance, strength and nature of the relationship between the above mentioned variables.

Results revealed that some demographic variables play significant role in explaining the variance in motivation, satisfaction and performance. Both satisfaction and motivation found to play important role in predicting work performance, whereas job satisfaction found to be significantly and positively related to work motivation. Implications of the findings for both practitioners and researchers are also discussed in the paper with some recommendations for future research in the field.
\end{abstract}

Keywords: Healthcare, job satisfaction, performance, motivation variables and Middle East.

\section{INTRODUCTION}

This paper aims to bridge the current gap that exists, especially in the UAE and the Middle East, regarding the understanding of motivation, satisfaction and performance in healthcare industry. The significance, level and the nature of the links between these variables as well as the demographic variable remained unexplored in the public sector's healthcare in the UAE.

Motivation is an important subject area for researchers and practitioners of management all over the world. Motivation is equally relevant to public and private sectors and civil and military establishments. It seems to be only motivation can get organisations out of the current global downturn. It is as relevant to charity organisations as it is to the commercial organisations. Increasingly, large manufacturing organisations and other establishments are using the services of industrial psychologists to solve the motivation and morale problems of their staff. Further, more and more companies of all sizes, large, medium or small are offering performance based incentives and rewards to keep their staff motivated. More and more companies are offering long service bonuses to retain skilled and competent staff and to minimise the rates of staff turnover. Any army that is not sufficiently motivated cannot win a war against its enemies. Similarly, a work force which is not sufficiently motivated cannot meet the objectives of its organisation whether the organisation is a profit making organisation or a not-forprofit organisation. Motivation is concerned with the human beings working in a particular place and companies all over the world are spending considerable amounts of money to set up an effective human resources (HR) department for their organisations.

*Address correspondence to this author at the British University in Dubai, Block 17, Knowledge Village, Dubai, United Arab Emirates;

E-mail: Abubakr.suliman@buid.ac.ae
Unfortunately, healthcare establishments have been evidently slow to recognise the importance of human element in their organisations. They have been late to realise that doctors, nurses and paramedical staff are also human beings and need to be motivated. Private hospitals have been first to recognise the fact and have introduced motivation programmes for their staff. However, the government health sector, where patients flow is substantially higher than in private hospitals, have been slow to catch up and implement the concept of motivation.

UAE offers world class healthcare services to its citizens and the expatriate population. The government hospitals in UAE employ the best of men, machinery and methods to deliver excellent medical services. However, even the most modern and sophisticated medical equipment and the most effective healthcare procedures become ineffective unless there is a sufficiently motivated team of staff to run the equipment and follow the procedures.

The current research investigates the role of demographic factors including marital status, age, and education in affecting the levels of employees work motivation and job satisfaction. Besides, examining the links, if any, between work motivation, job satisfaction and work performance.

\section{LITERATURE REVIEW}

\section{Work Performance}

According to Armstrong and Baron [1] performance management is a strategic and integrated approach to deliver sustained success to organisations by improving the performance of people who work in them and by developing the capabilities of teams and individual contributions. Performance management incorporates the review of past performance and the setting of objectives for the future (McKenna and Beech) [2]. Thus, performance management 
refers to the process where managers and their subordinates share understanding about what has been accomplished and what has to be accomplished. It helps in the continuous improvement of business performance through a coordinated programme of people management interventions or systems. One of the most important steps in performance management is performance measurement. It identifies the need for employee motivation which is a proper system that tells how bad or good the employees are performing and that whether there is a strong need for employee motivation strategies. Once employee performance is measured against the set goals and objectives, a need can be identified about the future strategies of employee motivation. Employee motivation is studied in the following sub head.

\section{Work Motivation}

On the other hand, Limited information and literature is available on motivating public sector employees, especially in public sector health care industry. The ability to motivate employees is a fundamental requirement of effective management in the workplace. Motivation concerns "those psychological processes that cause the arousal, direction and persistence of behaviour" (Ilgen and Klein, 1988). Motivated employees help organisations survive and succeed in the competitive environment. Rainey [3] states that work motivation "refers to how much a person tries to work hard and well - to the arousal, direction, and persistence of effort in work settings". Review of the literature shows that identifying employee motivation is considered essential to understanding why an individual chooses one job over another and why some employees work hard and some do not. Robertson, Smith and Cooper [4] state that consideration of questions such as; why do people go to work, why do people work hard? clearly shows that effort and performance at work are determined by ability, temperament and motivation. Despite the often complex interactions between these factors it is possible to develop theories and practical guidelines that focus specifically on motivation without losing sight of the influence of other factors. Behn [5] argued that one of 'big' questions that scholars of public management should be attempting to answer is: how public managers can motivate public employees to achieve goals. Baldwin [6] asked whether there would be a difference in the motivation level of public and private sector employees as a result of differing instrumental incentives (e.g., lower pay in the public sector), he found no difference. Jurkiewicz, Massey and Brown [7] found that public and private sector employees want different things from their jobs. Frederickson and Hart [8] contended that it is assumed that a significant reason why people enter the public service is some feeling of patriotism. Baldwin [9] stated that public employees place greater importance on job security than do private employees. Crewson [10] debated that non-pecuniary inducements - especially the opportunity to serve society and the public interest-matter more to public than private employees and high pay matters less to public than to private employees.

Volcker [11] states that polls show that the public believes government employees "work less hard" and are less productive than their private sector counterparts. The image of the federal service is that its members are lazy, unambitious, and less than competent (Meier) [12]. Baldwin
[6] found no difference between public and private managers' motivation levels. Upon analysis of several large federal surveys, Brehm and Gates [13] found federal employees working harder than private sector's employees.

These conflicting findings related to public-sector employees have forced researchers to do more researches on public sector employee motivation. Moe [14] argued that the belief that extrinsic rewards and punishments are the primary sources of work motivation may underlie the popular perception of the lazy bureaucrat, as governments face more obstacles than businesses in using compensation or discipline to motivate managers and employees as the processes and decision making is long. Another factor is that public sector managers cannot share in profits if their agencies perform well, and they do not lose their jobs if their agencies fail. Consequently, governments have fewer material incentives to extract high performance (Johnson \& Libecap) [15]. Loverich [16] examined the motivational effects of workplace participation and job enrichment in public employee in the State of Washington, USA. Workplace participation is found statistically significant on measure of employee motivation. Simons and Enz [17] studied the public employees in hotel industry and found that hotel works ranked "good wages," "job security," and "opportunity for advancement" as their top three work motivational factors.

The literature research showed that public hospitals face distinct types of problems other than the problems faced by healthcare industry. Public hospitals are in dire financial straits. Majority of the patients do not pay for medical services received by them. Public hospitals operate in a hostile environment: budget reductions, the rapid proliferation of competing healthcare alternatives with a much better image and the fashion of privatization (even of safety net institutions). They are heavily dependent on state funding and they make no routine statistical measurements of their effectiveness and productivity: wait times, financial reporting and the extent of network development (Vaknin) [18]. As the public sector healthcare industry is going through reforms, keeping employee motivation high especially during the reform period is quite a challenge for managements. Bennett and Franco [19] stated that attempts to advance quality and efficiency of the overall health care system through human resource management approaches have very evident links to health worker motivation. Typical efforts which have been taking place in the public sector healthcare industry include improving education and training as a means of incentives as well as to improve their capacity to perform; to restructure salary scales; and linking employee performance to rewards schemes through performance appraisals and performance related pay.

Some key researches had been undertaken on UAE on the subject of performance management and employee motivation. Suliman [20] distinguishes employee performance into self-rated performance and immediatesupervisor rated performance. He surveyed 1,285 employees and managers from 29 organisations in UAE using questionnaires and the results reveal a clear gap between employees' perceptions of their performance and their managers' perceptions. The survey revealed that employees in the UAE rated their performance more positively than 
their immediate supervisor. Suliman [21] undertook a selfadministered survey of 1000 employees from 20 industrial companies. The results revealed that organisational commitment and its two factors (normative and continuance commitment) play different roles in mediating the relationship between perceived work climate and performance, as rated by the employees themselves and their immediate supervisors.

Apart from what discussed above no research has been found on the employee motivation and performance in public sector health care in UAE. Similarly, literature search revealed that no studies were found on employee motivation in public sector health care in the Middle East and GCC countries.

\section{Hypotheses}

Based on the above discussion; the following hypotheses are developed to investigate the nature, level and significance of the relationships between the study variables:

H.1. Demographic variables will show significant relationships with motivation, satisfaction and performance in UAE's healthcare industry.

H.2. Motivation and job satisfaction will play significant role in explaining the variance in work performance in UAE's healthcare industry.

H.3. Job satisfaction will significantly explain the variance in motivation in UAE's healthcare industry.

\section{METHODS}

\section{Study Sample}

A self-administered questionnaire was developed by the researchers in order to survey employees of a UAE public sector hospital, total of 450 employees which include 86 doctors (general practitioners, specialists and consultants), 53 administrators (under varied job description, grades and categories), 77 technicians and 234 nursing staff. It was decided that 300 employees would be included in the survey. Table 1 below summarises the process of distribution and collection of questionnaires:

Table 1. Summary of Questionnaires Distributed and Received

\begin{tabular}{|l|c|}
\hline Total number of employees & 450 \\
\hline Sample of employee surveyed & 300 \\
\hline Replies received & 245 \\
\hline Response rate & $81.6 \%$ \\
\hline Useable questionnaires & 185 \\
\hline Percentage of useable questionnaires & $61.6 \%$ \\
\hline
\end{tabular}

\section{Measurement of Variables}

The variables used in this research are demographic variables (sex, marital status, education, age, hospital tenure, job tenure, job status and nationality), motivation, satisfaction and performance. The relationships of these variables with work motivation, job satisfaction and self rated performance were studied through the regression analysis.

Using Likert's 5-point scale motivation, satisfaction and performance were measured using scales developed by the researchers.

\section{FINDINGS AND DISCUSSION}

The collected data of the study is analysed using the SPSS programme. Table 2 shows the description of the study sample.

The above results show that majority of the respondents who replied were female, married, had graduate degree, between 25-35 years of age, had been working in the hospital and in their current jobs for 2-7 years, were middle level employees and were non-UAE nationals.

The reliability test was applied, the findings revealed that the alpha value $(\alpha=.77)$ of the study instrument is highly reliable. The relationship between the independent variables was tested using the correlation test. Table 3 below exhibits the results of correlation analysis.

As can be seen from the table, number of years worked in the hospital is correlated with education $(r=.27)$ and age $(r$ $=.24)$. The positive correlation coefficient indicates that there is a statistically significant $(p<0.05)$ linear relationship between these two variables. This means people working in the hospital for longer time have more education and old age. This could be attributed to the employee development programme that most UAE hospitals practice. Some other significant correlations between demographic variables were also reported, namely education $/ \operatorname{sex}(r=.17)$, job tenure/education $(r=-.15)$ and nationality/job tenure $(r=-.15)$.

Work motivation reported positive and significant relationships with Gender $(r=.19)$, education $(r=.19)$, age $(r=.16)$, organisational tenure $(r=.22)$, nationality $(r=.16)$. Likewise, job satisfaction reported significant and positive relationship with education $(r=.16)$, organisational tenure $(r$ $=.22)$ and nationality $(r=.18)$. Further, work performance showed more stronger, significant and positive relationships with demographic variables, namely, education $(r=.23)$, age $(r=.17)$, organisational tenure $(r=.27)$ and nationality $(r=.17)$.

Descriptive statistics (e.g. crosstabs) was also used to further analyze the relationships between demographic variables and satisfaction, motivation and performance. The results revealed that females showed higher levels of motivation than males. Generally females have less chances of employment, especially in Arabic countries. Therefore, they are likely to show high levels of enthusiasm and motivation than their male counterparts. In this context, Suliman [22] studied loyalty and performance in an Arabic context. He argued:

\footnotetext{
... the Jordanian Constitution clearly states that males and females are equal before the law, have the right to assume public office, and the right to work. In reality, this equality right offered by the law to female members of society does not exist. Jordanian society, like other Arab societies is reluctant to abandon its
} 
Table 2. Sample Description

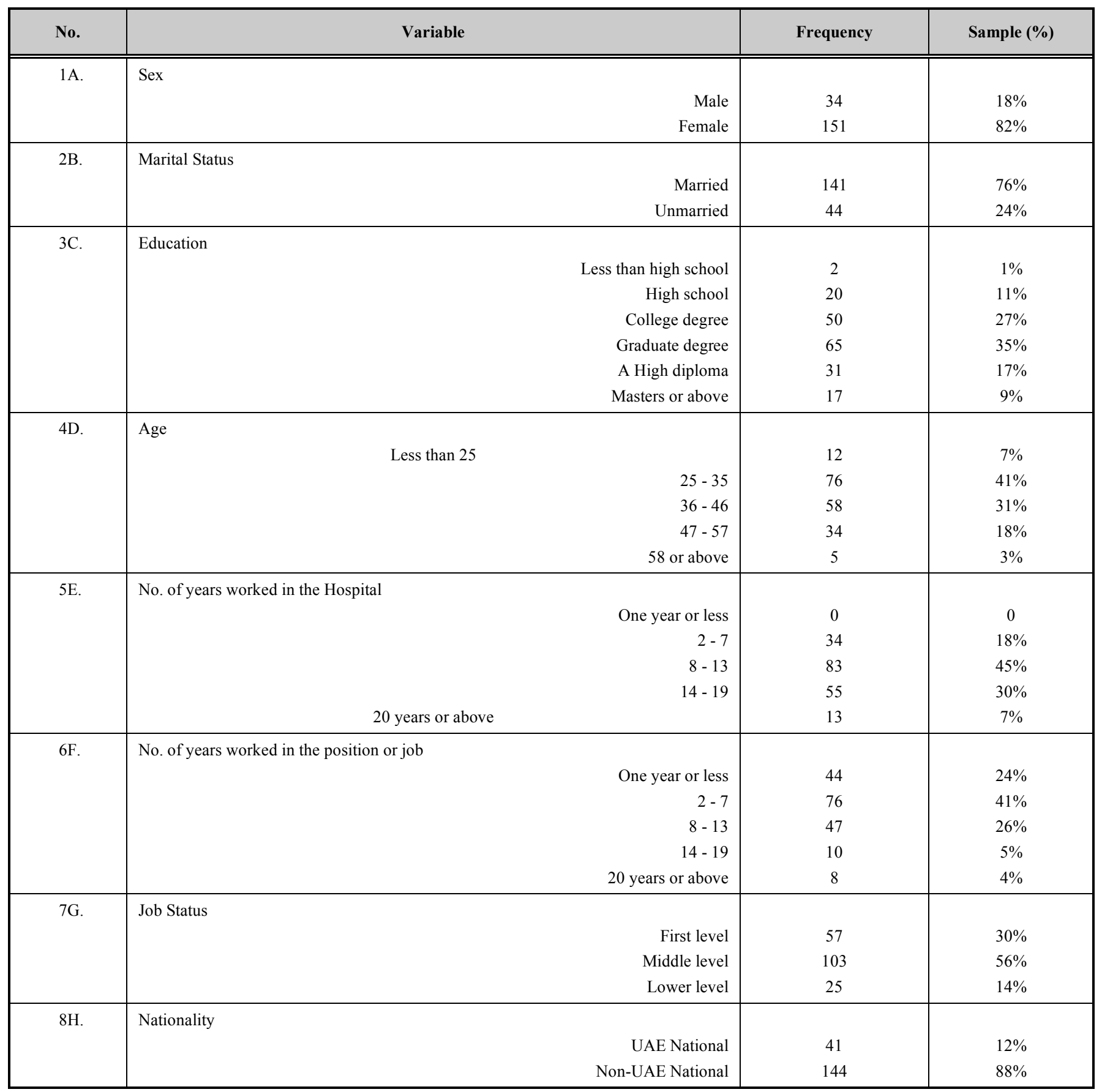

traditional view of women as primarily committed to the house and children (p. 126).

The tendency of older employees with higher levels of education, longer organisational tenure to showed higher levels of motivation can be explained by two reasons. Firstly, older employees who are well educated are likely to receive higher organisational rewards, and sometimes less work load, than less educated employees and/or younger people do. Secondly, the longer tenure employees tend to show higher levels of organisational commitment than shorter tenure employees, because they have been associated with their organisations for some time and, thus, may have ascended to better positions, or simply have enjoyed working there (Suliman [22]; Abdulla and Shaw [23]; Salancik [24], Schneider [25] and Suliman [17]). This supports the common argument in the management literature that motivated employees are normally committed to their organisations (e.g., Mowday et al. [26]). For example, the meta-analysis study results of Mathieu and Zajac [27] revealed that the "overall motivation exhibited a corrected correlation of $r_{t}=.563$, with $100 \%$ of the variance across five studies accounted for by artifacts" (p. 182). Similarly, Abdulla and Shaw 23[1], Salancik [24], Schneider [25], Suliman [25] and Mowday et al. [28]). For example, the meta-analysis study results of Mathieu and Zajac [27] Orpen [29] and Welsch and La Van [30] found that work motivation tended to positively and significantly influence 
Table 3. Correlation Analysis

\begin{tabular}{|c|c|c|c|c|c|c|c|c|c|c|c|}
\hline Variable & Sex & $\begin{array}{l}\text { Marital } \\
\text { Status }\end{array}$ & Education & Age & $\begin{array}{l}\text { No. Years } \\
\text { Worked } \\
\text { in the } \\
\text { Hospital }\end{array}$ & $\begin{array}{l}\text { No. of } \\
\text { Years in } \\
\text { Position }\end{array}$ & $\begin{array}{c}\text { Job } \\
\text { Status }\end{array}$ & Nationality & $\begin{array}{c}\text { Job } \\
\text { Satisfaction }\end{array}$ & $\begin{array}{c}\text { Work } \\
\text { Motivation }\end{array}$ & $\begin{array}{c}\text { Work } \\
\text { Performance }\end{array}$ \\
\hline Marital Status & .01 & 1 & & & & & & & & & \\
\hline Education & $.17^{*}$ & .09 & 1 & & & & & & & & \\
\hline $\begin{array}{l}\text { No. years } \\
\text { worked in the } \\
\text { hospital }\end{array}$ & .01 & .07 & $.27 * *$ & $.24 * *$ & 1 & & & & & & \\
\hline $\begin{array}{l}\text { No. of years in } \\
\text { the position }\end{array}$ & -.14 & .04 & $-.15^{*}$ & -.06 & -.11 & 1 & & & & & \\
\hline $\begin{array}{c}\text { Work } \\
\text { Motivation }\end{array}$ & $.19^{* *}$ & .5 & $.19 * *$ & $.16^{*}$ & $.22 * *$ & -.09 & .10 & $.16^{*}$ & $.23^{* *}$ & 1 & \\
\hline $\begin{array}{c}\text { Work } \\
\text { Performance }\end{array}$ & .10 & -.02 & $.23 * *$ & $.17^{*}$ & $.27 * *$ & .10 & .04 & $.17^{*}$ & $.53^{* *}$ & $.57 * *$ & 1 \\
\hline
\end{tabular}

** Correlation is significant at the 0.01 level (2-tailed).

$*$ Correlation is significant at the 0.05 level (2-tailed).

commitment. Furthermore, Staw [31] found that the Japanese model of motivation emphasises attachment, cooperation, achievement of organisational goals, extending extra effort on behalf of the organisation, and loyalty and service to the long-term interests of the organisation. Hence, motivated employees tend to show higher levels of organisational commitment, because the rewards they receive from the organisation positively influence their morale and bind them to be committed.

As mentioned above, older employees who are well educated, have longer organizational tenure showed higher levels of work performance. These findings replicate some results reported in the management literature. Baruch [32] and Liden et al. [33] for example, found no relationship between age and performance. However, Ferris [34] argued that junior level employees' age and performance are negatively related, while senior level employees' age is positively related to performance. Aged employees with longer organizational tenure are likely to have gained good work and cultural experience therefore they are likely to report higher levels of work performance.

As mentioned above, nationality (UAE/non-UAE) showed significant and positive relationship with job satisfaction $(r=.18)$, work motivation $(r=.16)$ and work performance $(r=.17)$. These findings were further explored using descriptive statistics. Findings revealed that non-UAE employees showed higher levels of job satisfaction, motivation and performance than local employees. Normally, in the UAE, the expectations of local employees from the organisation are far more than that of the expatriate employees. Suliman [35] examined the labour market in the UAE. He argued that UAE nationals are reluctant towards employment in traditional, manual and/or technical jobs, such as draughtsman, system analyst and secretary. And that the majority of them seek employment in the government departments where they work as executives or any other

work of a clerical nature with more benefits, such as high salary suitable working hours and social prestige. Expatriate employees, on the other hand, have limited choices, opportunities and accordingly less or lower levels of expectations from their employers. Therefore, they tended to show higher levels of satisfaction, motivation and performance than their local counterparts.

Given the above findings and discussion it can be concluded that hypothesis (1) is partially established and that some demographic factors, included in this study, are significantly related to motivation, satisfaction and performance.

Multiple regression analysis was also applied in order to examine hypotheses (2) and (3). Both motivation and satisfaction were regressed against work performance. The results are presented in Table $\mathbf{4}$ below:

The ANOVA and Model Summary part of Table $\mathbf{4}$ shows that the $F$ value of .86 .8 is highly significant, $R$ value is .70 and the adjusted $\mathrm{R}$ square value is .484 . This means that both motivation and satisfaction can explain up to $48.4 \%$ of the variance in work performance. The Coefficients part of Table 4 provides some further details and states that work motivation with beta weight of .47 is more important than job satisfaction (beta .42) in predicting the change in performance. Moreover, the correlation test results presented in Table 3 reveal that work motivation has more stronger, positive and significant relationship with performance $(r=$ $.57)$ than job satisfaction do $(r=.53)$. 
Table 4. Regression Analysis Results for Motivation, Satisfaction and Performance

Model Summary

\begin{tabular}{|c|c|c|c|c|}
\hline Model & R & R Square & Adjusted R Square & Std. Error of the Estimate \\
\hline \hline 1 & $.700^{(\mathrm{a})}$ & .489 & .484 & 4.42 \\
\hline
\end{tabular}

${ }^{a}$ Predictors: (Constant), work motivation, job satisfaction.

ANOVA

\begin{tabular}{|c|c|c|c|c|c|c|}
\hline \multirow{2}{*}{ Model } & & Sum of Squares & df & Mean Square & F & Sig. \\
\hline \hline \multirow{2}{*}{1} & Regression & 3397.696 & 2 & 1698.848 & 86.755 & .000 \\
\cline { 2 - 7 } & Residual & 3544.386 & 181 & 19.582 & & \\
\cline { 2 - 7 } & Total & 6942.082 & 183 & & \\
\hline
\end{tabular}

Coefficients $^{(\mathbf{a})}$

\begin{tabular}{|c|c|c|c|c|c|c|}
\hline \multirow{3}{*}{ Model } & & \multicolumn{2}{|c|}{ Unstandardized Coefficients } & Standardized Coefficients & t & Sig. \\
\cline { 3 - 8 } & & B & Std. Error & Beta & -2.271 & .024 \\
\hline \hline \multirow{2}{*}{1} & (Constant) & -10.374 & 4.568 & & 7.709 & .000 \\
\cline { 2 - 8 } & Job satisfaction & .497 & .065 & .421 & 8.618 & .000 \\
\cline { 2 - 8 } & Work motivation & .513 & .060 & .470 & & \\
\hline
\end{tabular}

These findings mirror some results reported in some nonMiddle Eastern studies. Clark [36] for example, called for fostering the work motivation of individuals and teams as it has a direct impact on their performance. He argued:

\begin{abstract}
Solid evidence supports claims that motivational programs can increase the quality and quantity of performance from 20 to 40 percent. Motivation can solve three types of performance problems: 1) people are refusing to change; and/or 2) allowing themselves to be distracted and not persist at a key task; and/or 3) treating a novel task as familiar, making mistakes but not investing mental effort and taking responsibility because of overconfidence (p. 21).
\end{abstract}

Clark called for finding ways to support the great variety of different individual and cultural beliefs held by different people about success and what makes them effective at work.

This result supports the argument that well motivated employees are generally good performers (Mowday et al [26]; Katz [37]). Employees who are satisfied with their motivation climate are likely to rate their performance highly, because they feel that, following the creation of a positive motivation environment, the organisation will expect them to be good performers. The relationship between motivation and performance reported in this study is consistent with the classic motivational framework offered by some scholars. Katz [37] for example, asserted that organisations need to motivate their members to (1) join and remain in the organisation, (2) perform their assigned duties dependably, and (3) exhibit "innovative and spontaneous behaviours" (p. 132). Likewise, Speen [38] suggested that employees' performance could be optimised by using motivational programs. He asserted:

People work better and get more done in an
environment where they are appreciated and
incentive programs help create that
atmosphere. In fact, when an employer uses
motivational programs, employees feel that the
company is concerned for their welfare and
wants to recognise their accomplishments.
Companies can optimise employee performance
by engaging in a continuing, organised
program of [promotion, motivation,
communication and recognition] ... With an
incentive or motivation program, we attempt to
obtain some level of additional performance in
exchange for some extra compensation
(reward). The difference is that you usually get
more for your money from the extra level of
performance (p. 2).

In addition, a few studies (e.g., Orpen [29] and Jackofsky and Slocum [39]) have reported that motivation and performance are not significantly related. Suliman [22] examined the relationship between work climate and performance in Jordanian industries. He found that work motivation was the most significant factor of climate in predicting performance, i.e. it was found to be positively and significantly related $(r=.39, \mathrm{p}<.001)$ to performance. The employees who reported positive perceptions of work motivation showed higher performance. Mendonca and Kanungo [40] examined employees' motivation and effective reward management in developing countries. They argued that the reward system must be designed and 
managed in a way that supports the organisation's mission and strategies. They contended that that the reward system is crucial to organisations, and that it contributes to maintain employee moral and, more importantly, it motivates workers to prepare themselves for great responsibilities. Besides being, the reward system, a powerful motivational tool in the hands of management.

Meanwhile, attempting to understand the nature, direction and significance of the link between job satisfaction and work performance is not easy. For at least 60 years organizational/industrial psychologists have been wrestling with the question of the relationship between job satisfaction and performance. It continues to be an issue of ongoing debate and controversy relationship between job satisfaction and job performance. Scholars, mostly westerners, have put a considerable amount of efforts in order to demonstrate that the two are positively linked, i.e. a happy worker is a good producer. Nevertheless, the results of empirical literature are too mixed to support the hypothesis that job satisfaction leads to better performance or even that there is a significant positive correlation between these two variables. Iaffaldano \& Muchinsky [41] analysed and reviewed the management literature to explore the link between satisfaction and performance. They concluded that the statistical correlation between job satisfaction and performance was about 0.17. Judge, Thoresen, Bono, and Patton [42] found that when the correlations are appropriately corrected (for sampling and measurement errors); the average correlation between job satisfaction and job performance is a higher .30. Saari and Judge [43] studied employee attitudes and job satisfaction. They concluded that the study of the relationship between job satisfaction and performance has a controversial history and that:
Greater insights on the relationship between employee attitudes and business performance will assist HR professionals as they strive to enhance the essential people side of the business in a highly competitive, global arena (p. 404).

Given the above results and discussions it be concluded that hypothesis (2) is fully established and that both work motivation and work performance play significant role in predicting the variance in work performance.

To examine hypothesis (3) both multiple regression and correlation test were applied. Table $\mathbf{5}$ summarises the findings of regression test. As can be seen from the table, the F value of 10.521 is highly significant $(\mathrm{p}<.001), \mathrm{R}=.233$, adjusted $\mathrm{R}$ square .054. This means that job satisfaction plays significant role in influencing work motivation and that it explains $5.4 \%$ of the total variance in motivation. The coefficient part of Table 5 shows that the $t$ value (3.244) of job satisfaction is highly significant with a beat weight of .233. Recalling the findings of correlation test presented in Table 3 job satisfaction has a significant and positive relationship ( $r=.23)$ with work motivation.

The correlation that exists in this study among perceived work motivation and job satisfaction corresponds with Brown and Shepherd [44] who reported that motivation improves workers' performance and job satisfaction. Positing that competitiveness problems appear to be largely motivational in nature, Tella, Ayeni and Popoola [45] examined work motivation, job satisfaction, and organisational commitment in Nigeria. They found that satisfaction and motivation are significantly and positively related $(r=.41)$.

Table 5. Regression Analysis Findings for Satisfaction and Performance

Model Summary

\begin{tabular}{|c|c|c|c|c|}
\hline Model & R & R Square & Adjusted R Square & Std. Error of the Estimate \\
\hline \hline 1 & $.233^{(\mathrm{a})}$ & .054 & .049 & 5.50084 \\
\hline
\end{tabular}

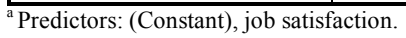

ANOVA

\begin{tabular}{|c|c|c|c|c|c|c|}
\hline \multirow{2}{*}{ Model } & & Sum of Squares & df & Mean Square & F & 10.521 \\
\hline \hline \multirow{2}{*}{1} & Regression & 318.345 & 1 & 318.345 & .001 \\
\cline { 2 - 7 } & Residual & 5537.439 & 183 & 30.259 & & \\
\cline { 2 - 7 } & Total & 5855.784 & 184 & & \\
\hline
\end{tabular}

Coefficients $^{(a)}$

\begin{tabular}{|c|c|c|c|c|c|c|}
\hline Model & & \multicolumn{2}{|c|}{ Unstandardized Coefficients } & Standardized Coefficients & t & Sig. \\
\hline & & B & Std. Error & Beta & \\
\hline \hline 1 & (Constant) & 23.483 & 5.391 & .233 & 4.356 & .000 \\
\hline & Job satisfaction & .252 & .078 & .244 & .001 \\
\hline
\end{tabular}

${ }^{a}$ Dependent Variable: work motivation. 
Taking on board the above presentations and discussion of findings regarding the link between satisfaction and motivation it can be safely concluded that there is a moderate, positive and significant relationship between the two. And that $5.4 \%$ of variance in motivation is explained by job satisfaction.

\section{CONCLUSIONS AND RECOMMENDATION}

This paper attempted to explore the links between demographic variables, motivation, satisfaction and performance in the healthcare services- public sector- of the UAE. The results showed that some demographic variables (e.g. job tenure) have significant relationships with motivation, satisfaction and performance. Both satisfaction and motivation played significant role in predicting the variance in performance. However, work motivation found to be more important in explaining that variance. Further, job satisfaction reported a positive yet a significant relationship with work motivation.

To conclude satisfied people showed higher levels of motivation which in turn lead to higher levels of work performance. Put differently, if employees are satisfied about their job, pay, relation with co-workers, supervisory style and promotion chances they are likely to:

1. Have achieved there needs, or feel that there needs are met.

2. Accordingly they develop the right drives that make them work for the organization.

3. And feel satisfied with the organizational incentives.

This positive perception of work motivation is likely to arouse, energize, direct, and sustain behaviour and performance, i.e. to be reflected positively on employees' work outcomes, e.g. increasing quality and quantity of work.

Based on the findings of the current study some recommendations can be suggested for both practitioners and researchers. Managers in the UAE and mainly in the healthcare sector need to find ways to satisfy, motivate and retain employees and increase their performance, especially locals. Otherwise, they will discover they are losing their talented and creative workers to other organizations who are more prepared and willing to meet their needs and demands. The psychological contract (undeclared expectations) of both parties (employees/organization) need to be explored through surveys and interview. Moreover, organizations must understand that employees' work outcomes are influenced by their levels of motivation and satisfaction. And that satisfied and motivated employees are the 'right people' that they need to get the 'right things' done. Opening superior/subordinate dialogue is very essential to bridge gaps in expectations through developing and conducting biannual or annual satisfaction and motivation surveys. Provided that the current research is the first of its type in the healthcare sector in the UAE, further research is needed to examine the links between motivation, satisfaction and performance. Future research may also try to examine the role of perceived work motivation in mediating the link between satisfaction and performance. Unlike previous studies, the current study suggests that satisfied employees are likely to be more motivated to produce. Further research is needed to explore the role of job satisfaction in predicting work motivation in order to reach more general understanding across cultures about the links between satisfaction, motivation and performance.

\section{REFERENCES}

[1] Armstrong M, Baron A. Performance management: the new realities. London: Institute of Personnel and Development London 1998.

[2] McKenna E, Beech N. Human resource management: A concise analysis. FT Prentice Hall 2002.

[3] Rainey H. Work motivation. In: Golembiewski RT, Eds. Handbook of organizational behaviour. New York: Marcel Dekker 2001: pp. 19-39.

[4] Robertson I, Smith M, Cooper D. Motivation strategies: theory and practice. London: IPD 1992.

[5] Behn D. The big questions of public management. Public Admin Rev 1995; 55: 313-24.

[6] Baldwin N. Are we really lazy? Rev Public Personnel Admin 1984; 4: 80-9.

[7] Jurkiewicz C, Massey T, Brown R. Motivation in public and private organizations: A comparative study. Public Product Manage Rev 1998; 21: 230-50.

[8] Frederickson HG, Hart DK. The public service and the patriotism of benevolence. Public Admin Rev 1985; 45: 547-53.

[9] Baldwin N. Public versus private employees: Debunking stereotypes. Rev Public Personnel Admin 1991; 11: 1-27.

[10] Crewson PE. Public-service motivation: Building empirical evidence of incidence and effect. J Public Admin Res Theory 1997; 7: 499-518.

[11] Volcker P. Leadership for America: Rebuilding the public service (Rep. of the National Commission on the Public Service), Washington, DC: National Commission on the Public Service 1989.

[12] Meier KJ. Politics and the bureaucracy: Policymaking in the fourth branch of government. 3rd ed. Belmont, CA: Wadsworth 1993.

[13] Brehm J, Gates S. Working, shirking, and sabotage: Bureaucratic response to a democratic public. Ann Arbor: University of Michigan Press 1997.

[14] Moe TM. The new economics of organizations. Am J Polit Sci 1984; $28:$ 739-77.

[15] Johnson R, Libecap G. The federal civil service system and the problem of bureaucracy: The economics and politics of institutional change. Chicago: University of Chicago Press 1994.

[16] Loverich NP Jr. Merit pay and motivation in the public workforce: beyond technical concerns to more basic considerations. Rev Public Personnel Admin 1987; 7: 54-71.

[17] Simons T, Enz C. Motivating hotel employees. Cornell Hotel Restaurant Admin Q 1995; 36: 20-7.

[18] Vaknin S. The Sickly State of Public Hospitals. [accessed 12 December 2006]. Available from: http://www.talewins.com/health builders/hospitals.htm

[19] Bennett S, Franco LM. Public Sector Health Worker Motivation and Health Sector Reform: A Conceptual Framework, Major Applied Research 5 Technical Paper No. 1, Partnerships for Health Reforms. 1999, [accessed 10 November 2006]. Available from: http://www1.worldbank.org/wbiep/decentralization/ciesin/PNACH 204.pdf

[20] Suliman A. Organisational conflict and loyalty in Sudanese industrial firms: Unpublished MBA thesis. University of Jordan: Amman, Jordan 1995.

[21] Suliman A. Is it really a mediating construct? The mediating role of organisational commitment in work climate-performance relationship. J Manage Dev 2001; 212: 170-83.

[22] Suliman A. Perceived work environment, commitment and performance in Jordanian Industries: Unpublished $\mathrm{PhD}$ Thesis, Liverpool Business School: Liverpool, UK 2001.

[23] Abdulla M, Shaw J. Personal factors and organisational commitment: Main and interactive effects in the United Arab Emirates. J Manage Issues 1999; 11: 77-93.

[24] Salancik GR. Commitment and the control of organisational behaviour and belief. In: Staw BM, Salancik GR, Eds. New Directions in Organisational Behaviour, St. Clair Press: Chicago 1977; pp. 1-51.

[25] Schneider B. Antecedents and outcomes of organisational commitment. Admin Sci Q 1988; 22: 472-9. 
[26] Tella A, Ayeni C, Popoola S. Work motivation, job satisfaction, and organisational commitment of library personnel in academic and research libraries in Oyo State, Nigeria, Library Philosophy and Practice, 2007. Available from: http://www.webpages.uidaho. edu/ mbolin/tella2.htm

[27] Mathieu J, Zajac D. A review and meta-analysis of the antecedents, correlates, and consequences of organisational commitment. Psychol Bull 1990; 108: 171-94.

[28] Mowday R, Steers R, Porter L. The measurement of organisational commitment. J Vocat Behav 1979; 14: 224-47.

[29] Orpen C. The effects of formal mentoring on employee work motivation, organisational commitment and job performance. Learn Org 1997; 4: 53-60.

[30] Welsch H, La Van H. Inter-relationships between organisational commitment and job characteristics, job satisfaction, professional behaviour, and organisational climate. Hum Relat 1981; 34: 107989.

[31] Staw B. Organisational behaviour: A review and formulation of field outcome variables. Ann Rev Psychol 1984; 35: 627-66.

[32] Baruch Y. Self performance appraisal VS direct-manager appraisal: A case of congruence. J Manage Psychol 1996; 11: 50-65.

[33] Liden R, Stilwell D, Ferris G. The effect of supervisor and subordinate age on objective performance and subjective performance ratings. Hum Relat 1996; 49: 327-47.

[34] Ferris K. Organisational commitment and performance in professional accounting firms. Account Org Soc 1981; 6: 317-25.

[35] Suliman A. The situation of HRM in the United Arab Emirates: an exploratory study: Australian Business and Behavioural Sciences
Association International Conference: Industry, Market, and Regions, 29 September to 1 October, Adelaide: Australia 2006.

[36] Clark RE. Fostering the work motivation of individuals and teams. Perform Improve 2003; 42: 21-9.

[37] Katz R. Time and work: Toward an integrative performance perspective. In: Staw BM, Cumming LL, Eds. Research in Organisational Behaviour. USA: JAI Press 1980.

[38] Speen G. Maximising employee performance through motivation. Incentive 1998; $2-7$

[39] Jackofsky EF, Slocum. A longitudinal study of climates. J Org Behav 1988; 9: 319-34.

[40] Mendonca R, Kanungo M. Work motivation: Models for developing countries. New Delhi: Sage Publications 1994.

[41] Iaffaldano MR, Muchinsky PM. Job satisfaction and job performance: A meta-analysis. Psychol Bull1985; 97: 251-73.

[42] Judge T, Thoresen C, Bono J, Patton G. The job satisfaction-job performance relationship: A qualitative and quantitative review. Psychol Bull 2001; 127: 376-407.

[43] Saari L, Judge T. Employee attitudes and job satisfaction. Hum Resource Manage 2004; 43: 395-407.

[44] Brown J, Sheppard B. Teacher Librarians in Learning Organizations, Paper presented at the Annual Conference of the International Association of School Librarianship, August 25-30, Canada 1997.

[45] Mowday R, Porter L, Steers R. Employee-organisation linkages: The psychology of commitment and absenteeism and turnover. New York: Academic Press 1982

(C) Suliman and Al-Sabri; Licensee Bentham Open.

This is an open access article licensed under the terms of the Creative Commons Attribution Non-Commercial License (http://creativecommons.org/licenses/ by-nc/3.0/) which permits unrestricted, non-commercial use, distribution and reproduction in any medium, provided the work is properly cited. 